JOTE Volume 2 Nomor 1 Tahun 2020 Halaman 207-213 JOURNAL ON TEACHER EDUCATION

\title{
Implementasi Pendekatan Pembelajaran HOTS untuk Meningkatkan Kemampuan Berpikir Kritis Siswa SMP pada Mata Pelajaran Pkn Kelas IX.3
}

\author{
Winda Harniati \\ SMPN 1 Mempura
}

\begin{abstract}
Abstrak
High Order Thinking Skills merupakan suatu proses berpikir siswa dalam level kognitif yang lebih tinggi yang dikembangkan dari berbagai konsep dan metode kognitif dan taksonomi pembelajaran seperti metode problem solving, taksonomi bloom, dan taksonomi pembelajaran, pengajaran, dan penilaian. HOTS merupakan keterampilan berpikir yang erat kaitannya dengan mata pelajaran PKN. PKN dikenal sebagai ilmu yang melatih siswa dengan kemampuan berpikir kritis, logis, analitis, dan sistematis yang merupakan kemampuan HOTS.
\end{abstract}

Kata kunci: Pendekatan Pembelajaran, HOTS, PKN

\section{Abstract}

High Order Thinking Skills is a process of thinking of students in a higher cognitive level that is developed from various concepts and methods of cognitive and learning taxonomies such as the method of problem solving, bloom taxonomy, and the taxonomy of learning, teaching, and assessment. HOTS is a thinking skill that is closely related to social studies subjects. Social studies is known as a science that trains students with critical, logical, analytical, and systematic thinking skills which are HOTS abilities.

Keywords: Learning Approach, PIT, Critical Thinking

\section{PENDAHULUAN}

Dunia pendidikan memasuki era globalisasi yang penuh tantangan dan ketidakpastian, diperlukan pendidikan yang dirancang berdasarkan kebutuhan yang nyata di lapangan. Guru sebagai fasilitator yang mempunyai peran sentral dalam dunia pendidikan dituntut memiliki kreatifitas dalam hal mengelola pembelajaran. Pemilihan model pembelajaran menjadi penting karena ini akan menentukan diserap siswa dalam memahami pembelajaran.

Mata pelajaran Pendidikan Kewarganegaraan (PKN) di SMP dan MTs merupakan salah satu mata pelajaran yang wajib ditempuh oleh siswa SMP dan 
MTs sebagaimana yang diungkapkan oleh Sapriya (2009: 12) bahwa PKN pada kurikulum sekolah (satuan pendidikan), pada hakikatnya merupakan mata pelajaran wajib sebagaimana dinyatakan dalam UndangUndang Nomor 20 Tahun 2003 tentang Sistem Pendidikan Nasional pada pasal 37 yang berbunyi bahwa kurikulum pendidikan dasar dan menengah wajib memuat ilmu pengetahuan sosial. Mata pelajaran Pendidikan Kewarganegaraan (PKN), sebagai mata pelajaran yang wajib ditempuh oleh peserta didik, merupakan mata pelajaran yang disusun secara sistematis, komprehensif, dan terpadu sebagaimana yang tertuang dalam Permendiknas Nomor 22 Tahun 2006. Pembelajaran PKN yang disusun secara terpadu, memiliki tujuan agar peserta didik dapat memperoleh pemahaman yang lebih luas dan mendalam pada bidang ilmu yang berkaitan.

Pembelajaran PKN pada hakikatnya memiliki dimensi proses kemampuan berpikir, dimensi hasil (produk), dan dimensi pengembangan sikap. Ketiga dimensi tersebut bersifat saling terkait. Keterkaitan ketiga dimensi tersebut menyebabkan perubahan paradigma pada pelaksanaan pembelajaran. Pembelajaran yang awalnya berpusat pada guru (teaher centered) berubah menjadi berpusat pada siswa (student centered). Berubahnya paradigma tersebut haruslah seimbang dengan kreativitas guru dalam mengkombinasikan model pembelajaran. Salah satu kombinasi pembelajaran yang dapat menunjang ketiga dimensi tersebut adalah pembelajaran dengan HOTS (Higher Order Thinking Skills).

High Order Thinking Skills merupakan suatu proses berpikir siswa dalam level kognitif yang lebih tinggi yang dikembangkan dari berbagai konsep dan metode kognitif dan taksonomi pembelajaran seperti pembelajaran PIT, taksonomi bloom, dan taksonomi pembelajaran, pengajaran, dan penilaian. HOTS merupakan keterampilan berpikir yang erat kaitannya dengan mata pelajaran PKN. PKN dikenal sebagai ilmu yang melatih siswa dengan kemampuan berpikir kritis, logis, analitis, dan sistematis yang merupakan kemampuan HOTS (Higher Order Thinking Skills) oleh Saputra (seperti dikutip dalam Dinni, 2018).

Berdasarkan uraian diatas maka guru terdorong untuk Implementasi Pendekatan Pembelajaran HOTS Untuk Meningkatkan Kemampuan Berpikir Kritis Siswa Smp Pada Materi Bela Negara.

Rumusan masalah dalam penelitian ini adalah Bagaimana Implementasi Pendekatan Pembelajaran HOTS Untuk Meningkatkan Kemampuan Berpikir 
Kritis Siswa Smp Pada Materi Bela Negara. Sedangkan tujuan dari penelitian ini adalah untuk mengetahui Implementasi Pendekatan Pembelajaran HOTS dalam Meningkatkan Kemampuan Berpikir Kritis Siswa Smp Pada Materi Bela Negara.

Keterampilan berfikir tingkat tinggi atau dikenal dengan Higher order thinking skills (HOTS) pada taksonomi bloom merupakan urutan tingkat berfikir (kognitif) dari rendah ke tinggi. Pada ranah kognitifnya, HOTS berada pada level analisis, sintesis dan evaluasi. Oleh Krathworl \& Andrerson (seperti dikutip dalam Julianingsih, 2017) dalam Taksonomi Bloom yang telah direvisi kemampuan berpikir tingkat tinggi melibatkan analisis (C4), mengevaluasi (C5), dan mencipta atau kreativitas (C6) dianggap berpikir tingkat tinggi.

HOTS (Higher order thinking skills) berdasarkan pada keterampilan berpikir tingkat rendah seperti membedakan, penerapan dan analisis sederhana, dan strategi kognitif yang berhubungan dengan pengetahuan sebelumnya dari isi permasalahan pokok (kosakata, pengetahuan prosedural, dan pola memberi alasan). Strategi pengajaran yang sesuai dan lingkungan belajar yang memfasilitasi pertumbuhan kemampuan berpikir yang lebih tinggi seperti halnya ketekunan siswa, pemantauan diri, dan berpikiran terbuka, sikap fleksibel. (www.academia.edu, diakses 15 Oktober 2016).

HOTS merangsang siswa untuk mengintrepretasikan, menganalisa atau bahkan mampu memanipulasi informasi sebelumnya sehingga tidak monoton. HOTS memberikan dampak pembelajaran bagi siswa maupun guru yaitu: (1) belajar akan lebih efektif dengan higher order thinking; (2) meningkatkan kemampuan intelektual guru dalam mengembangkan higher order thinking; (3) dalam evaluasi belajar dengan konsep baru ini, guru harus selalu menyiapkan soal pertanyaan yang nantinya tidak dijawab secara sederhana. (Ariandari, 2015).

Keunggulan model HOTS (Higher order thinking skills) dibanding dengan model lain adalah dengan model HOTS siswa dapat membedakan ide atau gagasan secara jelas, berargumen dengan baik, mampu memecahkan masalah, mampu mengkonstruksi penjelasan, mampu berhipotesis dan memahami hal-hal kompleks menjadi lebih jelas. (Dinni, 2018)

Kelemahan model HOTS terletak pada kondisi kelas yang hiterogen. Perbedaan daya serap antar siswa menjadi kendala utama dalam penerapan model HOTS dalam pembelajaran. Dalam proses HOTS siswa dituntut berfikir aktif dan cepat, disisi lain seorang guru tentunya mengingatkan kesetaraan 
pemahaman konsep oleh keseluruhan siswa dalam kelas. Oleh karena itu, guru menjadi komponen penting dalam proses penerapan HOTS. Kreatif dan pandai melihat situasi kelas merupakan kemampuan yang dimiliki guru dalam menjalankan model HOTS.

Berdasarkan beberapa pendapat tersebut dapat disimpulan bahwa HOTS (Higher order thinking skills) merupakan proses berpikir yang tidak sekedar menghafal dan menyampaikan kembali informasi yang diketahui siswa baik informasi dari guru maupun dari media lain. Kemampuan HOTS merupakan kemampuan menghubungkan, memanipulasi, dan menstransformasi pengetahuan serta pengalaman yang sudah dilakukan oleh siswa dan merangsang pola berfikir kritis siswa.

Dalam kehidupan sehari-hari, kita sering mengajukan pertanyaan. Biasanya pertanyaan diajukan untuk mendapatkan informasi yang berguna untuk si penanya saja. Dalam konteks proses pembelajaran di sekolah, bertanya adalah cara paling efektif untuk meningkatkan keterampilan berpikir siswa, membuat siswa menjadi aktif, dan kreatif. Namun, masih banyak guru ketika mengajukan pertanyaan hanya menuntut siswa untuk mengulang gagasan guru daripada merangsang siswa membangun gagasan sendiri. Misalnya, bertanya: "Anak-anak, ibu kota Indonesia adalah Jakarta. Jadi, apa ibu kota Indonesia?" Siswa menjawab secara bersama atau "koor": "Jakarta!" Lain halnya kalau kemudian guru itu bertanya: "Mengapa Jakarta, bukan kota lain?" Jawaban pertanyaan ini belum dikemukakan guru. Pertanyaan itu lebih mendorong siswa untuk membangun gagasan sendiri dalam menjawabnya, bukan mengulang gagasan guru.

Dalam hal ini Pertanyaan HOST adalah untuk memperoleh jawabannya mendorong siswa untuk melakukan pengamatan, percobaan, dan/atau penyelidikan/eksplorasi. Dan pertanyaan HOTS bila jawabannya merupakan hasil imajinasi siswa. Sedangkan pertanyaan HOTS adalah mendorong siswa 'BERPIKIR HOTS' (memikirkan kemungkinan lain dari sesuatu) terkait jawabannya.

\section{METODE}

Jenis penelitian yang dilakukan adalah penelitian tindakan kelas kolaboratif yang bekerjasama dengan guru PKN di tingkat yang berbeda. Uno, dkk (2012) mengatakan bahwa PTK adalah penelitian yang dilakukan oleh guru di dalam kelasnya sendiri melalui refleksi diri, dengan tujuan untuk memperbaiki 
kinerjanya sebagai guru, sehingga proses pembelajaran dapat berjalan dengan baik, dan hasil belajar siswa meningkat. Arikunto, dkk (2014) mengatakan bahwa PTK merupakan suatu pencermatan terhadap kegiatan belajar berupa sebuah tindakan yang sengaja dimunculkan dan terjadi dalam sebuah kelas secara bersama. Dari keterangan diatas dapat disimpulkan penelitian tindakan kelas (PTK) adalah penelitian yang dilakukan oleh guru di dalam kelas melalui pencermatan terhadap kegiatan belajar dengan tujuan memperbaiki kinerja guru agar proses pembelajaran dapat berjalan dengan baik.

Penelitian ini dilaksanakan di kelas VIII.2 SMP Negeri 1 Mempura pada semester ganjil tahun pelajaran 2015/2016 dari tanggal 19 Agustus 2016 sampai tanggal 30 Oktober 2016. Analisis data tentang aktivitas siswa dan guru didasarkan pada lembar pengamatan dengan cara mendeskripsikan setiap aspek yang diamati selama proses pembelajaran untuk setiap pertemuan. Data tersebut dianalisis secara kualitatif guna untuk direfleksi.

Kriteria aktivitas siswa berpedoman pada kriteria aktivitas guru menurut Badan Pengembangan Sumber Daya Manusia Pendidikan dan Kebudayaan dan Penjaminan Mutu Pendidikan Kementerian Pendidikan dan Kebudayaan (2014). Terjadinya peningkatan aktivitas guru dan siswa jika nilai aktivitas guru dan siswa yang terlaksana setiap pertemuan semakin meningkat. Aktivitas guru dan siswa dikatakan semakin baik jika kriteria aktivitas guru dan siswa berada pada kriteria Baik (B) atau Amat Baik (AB).

\section{PEMBAHASAN}

Kesesuaian antara langkah-langkah penerapan pembelajaran HOTS yang direncanakan dengan pelaksanaan tindakan proses pembelajaran dapat dilihat dari lembar pengamatan pada setiap pertemuan (Lampiran). Data yang diperoleh melalui lembar pengamatan dan diskusi dengan pengamat tersebut dianalisis. Aktivitas guru pada pertemuan pertama belum sesuai dengan perencanaan. Pada kegiatan awal, guru kurang komunikatif dalam mengajukan pertanyaan yang dapat memancing ingatan siswa tentang materi yang telah dipelajari sehingga hanya tiga orang siswa yang mampu menjawab pertanyaan yang diberikan oleh guru. Pada saat pembentukan kelompok, kelas menjadi ribut karena siswa masih mencari posisi tempat duduk dan teman sekelompoknya sehingga guru harus mengatur posisi setiap kelompok yang akan ditempati siswa. Pada pertemuan kedua, guru lebih komunikatif sehingga siswa yang menjawab pertanyaan guru lebih meningkat dari pertemuan pertama. Pada saat 
pembentukan kelompok, siswa lebih tertib dan tenang karena siswa sudah hafal dimana posisi kelompok. Waktu pelaksanaan pada pertemuan kedua sudah mulai sesuai dengan perencanaan.

Pada kegiatan inti, aktivitas guru dan siswa semakin membaik pada setiap pertemuannya. Pada pertemuan pertama, masih banyak ditemukan kelompok yang mengalami kesulitan dalam mengerjakan LK. Pada diskusi kelompok, ada siswa yang masih bekerja secara individual dalam kelompok. Pada pertemuan kedua, guru menjelaskan kembali pengerjaan LK dan menegaskan kepada setiap siswa untuk bekerjasama dalam kelompok. Kerjasama kelompok pada pertemuan kedua lebih baik dari pertemuan sebelumnya. Pada tahap presentasi ada siswa yang tidak memperhatikan diskusi kelas. Aktivitas guru dan siswa pada kegiatan akhir juga semakin membaik setiap pertemuan. Pada pertemuan pertama guru masih kurang dalam pengelolaan waktu, sehingga waktu pelaksanaan proses pembelajaran tidak sesuai dengan perencanaan. Pada pertemuan kedua guru sudah melaksanakan proses pembelajaran sesuai dengan perencanaan dan telah mampu mengelola waktu seefisien mungkin. Sehingga diakhir siklus pertama, pelaksanaan kegiatan akhir sesuai dengan perencanaan.

Berdasarkan lembar pengamatan aktivitas guru dan siswa, nilai aktivitas siswa adalah 75,00. Menurut Badan Pengembangan Sumber Daya Manusia Pendidikan dan Kebudayaan dan Penjaminan Mutu Pendidikan Kementrian Pendidikan dan Kebudayaan (2014), $70<$ nilai $\leq 80$ memperoleh kriteria C (Cukup), sehingga dapat disimpulkan bahwa aktivitas siswa pada siklus pertama belum sesuai dengan indicator keberhasilan penelitian. Hal ini terlihat dari kriteria aktivitas siswa dan hasil belajar siswa pada kreteria cukup (C).

Pada siklus kedua guru berusaha memperbaiki kekurangan-kekurangan berdasarkan refleksi pada siklus pertama. Guru berusaha mengunakan bahasa yang komunikatif dalam memberikan motivasi maupun apersepsi. Guru juga berusaha melibatkan siswa terlibat aktif pada kegiatan awal pembelajaran dengan mengajukan pertanyaan-pertanyaan untuk mengetahui pemahaman siswa mengenai materi yang diberikan, sehingga aktivitas yang dilaksanakan pada kegiatan awal mengalami peningkatan pada setiap pertemuan dan sesuai dengan perencanaan.

Pada kegiatan inti, kerjasama setiap kelompok dalam mengerjakan LK terlihat semakin baik hingga akhir siklus kedua. Sikap bekerjasama dan tanggung 
jawab siswa juga semakin baik ketika diskusi kelompok dan diskusi kelas berlangsung. Namun di akhir siklus kedua masih ada ditemukan seorang siswa yang terkadang tidak memperhatikan pada diskusi kelas. Setelah guru menegur siswa tersebut, kemudian siswa memperhatikan diskusi kelas.

Pada kegiatan akhir, aktivitas guru dan siswa semakin sesuai dengan perencanaan. Hal ini berarti guru dan siswa pada kegiatan akhir siklus kedua semakin baik. Berdasarkan lembar pengamatan aktivitas siswa, nilai aktivitas siswa adalah 92,00. Menurut Badan Pengembangan Sumber Daya Manusia Pendidikan dan Kebudayaan dan Penjaminan Mutu Pendidikan Kementrian Pendidikan dan Kebudayaan (2014), 90< nilai $\leq 100$ memperoleh kriteria SB (Sangat Baik), sehingga dapat disimpulkan bahwa aktivitas siswa pada siklus kedua mengalami peningkatan karena aktivitas semakin baik. Hal ini terlihat dari kriteria aktivitas guru yang diperoleh adalah Baik dan kriteria aktivitas siswa yang diperoleh adalah Sangat Baik.

\section{KESIMPULAN}

Berdasarkan hasil penelitian yang telah guru lakukan dapat disimpulkan bahwa penerapan pembelajaran HOTS dapat Meningkatkan Kemampuan Berpikir Kritis Siswa SMP Negeri 1 Mempura Pada Materi Pembelaan Negarasemester ganjil tahun pelajaran 2015/2016.

\section{DAFTAR PUSTAKA}

Ariandari, W.P. 2015. "Mengintegrasikan Higher Order Thingking dalam Pembelajaran Creative Problem Solving. Seminar Nasional Matematika dan Pendidikan Matematika UNY 2015". Universitas Negeri Yogyakarta.

Arikunto, Suharsimi, dkk. 2014. Penelitian Tindakan Kelas. Jakarta: PT. Bumi Aksara.

Nur Dinni, H. 2018. HOTS (High Order Thinking Skills) dan Kaitannya dengan Kemampuan Literasi Matematika).

Sapriya. (2009) Pendidikan PKN. Bandung: Rosda Karya.

Uno, Hamzah B, dkk. 2012. Menjadi Guru PTK yang Profesional. Jakarta: PT. Bumi Aksara. 